\title{
Determinants of Consumer Instalment Credit in Transitional Country: The case of Vietnam
}

\author{
Do Hoai Linh \\ Finance, National Economics University \\ 207 Giai Phong Road, Hai Ba Trung District, Hanoi City, 100000, Vietnam \\ Email: linhdh@ neu.edu.vn; linhdo.neu@gmail.com; ORCID ID: 0000-0003-0274-2422
}

Dr (Economics), Lecturer and Researcher, Deputy Head, Department of Banking Management, School of Banking and

Received 23 April 2019;

Accepted 11 May 2019;

Published 25 May 2019

\begin{abstract}
The article aims at determining factors influencing on Consumer Instalment Credit (CIC) with the case of Vietnam. Primary data from in-depth interview and sample of 580 from respondents surveyed from September to December of 2018 showed that education level, interest rates; income, age of customer have strong impacts on the growth of CIC in emerging country. From these findings, recommendations for authority agencies and banks were proposed to develop CIC in transitional country.
\end{abstract}

Keywords: Consumer Instalment Credit, Transitional Country, Income, Education Level, Age.

\section{Introduction}

Consumer Instalment Credit (CIC) is an important tool to boost consumption and thereby contribute to the development of the economy. In emerging country, in recent years, the CIC market has started to grow strongly with the participation of more service providers and demand for consumer loans. However, CIC market has not reached the level of development commensurate with the potential (Park, 1993). In fact, in countries around the world, the consumer lending market has grown to have a major impact on the promotion of prosperity. This is achieved through the benefits it brings to consumers, the financial system and businesses in the economy (UN, 2015). Although, the development of CIC to lay the foundation for the commercial banking system and financial companies to operate, create a healthy competitive market, CIC market in emerging country such as Vietnam still keep a lag pace with the development of the world market. For that reasons, the authors aim at investigating factors affecting the growth of CIC in Vietnam, therefore, several recommendations were proposed to enhance accessibility of consumer with these kinds of loans.

\section{Situation of consumer instalment credit}

\subsection{Growth of consumer instalment credit worldwide}

Consumer credit is understood as a financing form for the spending purposes by individuals and households. Consumer loans are an important financial source for consumers to cover their living needs such as housing, transportation, accommodation, study, travel and health... before they are financially able to enjoy these demands (BGOFRS, 2006). CIC includes almost short-term and intermediate-term loans for individuals which are planned in two or more instalments, and the payments are the same amount every month. It's not includes loans secured by real estate. Three main categories in CIC including automobile credit, revolving credit and other credit. In that, revolving credit is almost credit card loans, and other credit covers loans to finance purchase of mobile homes, home appliances and furniture, and personal loans. Commercial banks, finance companies, credit unions, savings institutions, retailers and gasoline companies are all the lenders.

Table 1: Proportions of Households using credit, 1951-2010, in percent

\begin{tabular}{|c|c|c|c|c|c|c|c|c|c|c|c|c|}
\hline Types of credit & 1951 & 1956 & 1963 & 1970 & 1977 & 1983 & 1989 & 1995 & 2001 & 2004 & 2007 & 2010 \\
\hline Closed - end instalment credit & 32 & 45 & 50 & 49 & 49 & 41 & 44 & 45 & 44 & 46 & 46 & 46 \\
\hline $\begin{array}{l}\text { Have auto credit (part of closed-end } \\
\text { instalment credit) }\end{array}$ & 26 & 21 & 26 & 29 & 34 & 28 & 33 & 31 & 34 & 35 & 34 & 30 \\
\hline Credit card with revolving balance & NA & NA & NA & 22 & 34 & 37 & 40 & 47 & 44 & 46 & 46 & 39 \\
\hline Have any credits card & NA & NA & NA & 51 & 63 & 65 & 70 & 74 & 76 & 75 & 73 & 68 \\
\hline Have bank- type credit card & NA & NA & NA & 16 & 38 & 43 & 56 & 66 & 73 & 71 & 70 & 65 \\
\hline $\begin{array}{l}\text { Have revolving balance on bank-type credit } \\
\text { card }\end{array}$ & NA & NA & NA & 6 & 16 & 22 & 29 & 37 & 39 & 40 & 41 & 34 \\
\hline Consumer credit & 46 & 53 & 59 & 54 & 61 & 61 & 62 & 64 & 63 & 64 & 66 & 61 \\
\hline
\end{tabular}

Source: (BGOFRS, 2006) 
The table illustrates the percentage of households using credit from 1951 to 2010 in America. In general, the table fluctuated and all items in table slightly increased, it shown that people tend to use credit more and more. At the beginning, those who use CIC approximate 32 percent and after about a decade it was risen up to 50 percent, the highest point of period. From 1970 to 2010, closedend instalment credit insignificantly declined and maintained around 41 to 49 proportions. In 1970, credit card had more details on use and increase rapidly, such as bank-type credit card. There was a quick improvement in the percentage of American households using accounting for a scanty $20 \%$ in 1970 to $73 \%$ in 2001 and unchanged until 2010 around 70 percent (Gene Amromin, Leslie McGranahan \& Diane Whitmore Schanzenbach, 2015). Consumer credit and mortgage credit also have the same changes in using. For starters, the figure of customers was 46 percent for CC and 20\% for MC. Both of them are slowly rise and peak at 66 percent and 46 percent in 2007. To combine the sorts of credit usually used, it was ups and downs around 63 to 75 percent.

\subsection{Growth of consumer instalment credit in Vietnam}

In 2016, consumer lending maintained its strong performance thanks to the improving economy. With rising incomes, Vietnamese people are more willing to spend money in order to improve their living standards and level of comfort. Leveraging this opportunity, banks and financial companies are becoming more flexible in terms of application processes and documents. In addition, processing times are becoming much shorter, with some operators offering loans within just 10-15 minutes. As a result, consumers are becoming more comfortable with borrowing money, thus contributing to the good performance of consumer lending in 2016 (StoxPlus, 2017). Financial firms and commercial banks providing this kind of service still largely ignored the outskirts and rural areas, where there were a large number of people who don't qualify for banking loans, who were potential customers for consumer credit. The central bank's statistics showed that outstanding consumer loans accounted for 8 per cent of the economy's total outstanding loans, which was modest in comparison with the regional average of around 20 per cent and 40 per cent in developed financial markets. Interests from consumer lending remain higher than banking rates. This is understandable because it is difficult for financial companies to raise capital, while their lending costs are higher and loans are mainly trust-based. As the market had not developed risks remained high, and added that the development of consumer lending would promote competition, which was expected to lower interest rates with regard to consumer lending. Still, experts said that interest rates from consumer lending were much lower than black credit. The development of consumer lending would bring a lot of benefits not only to the consumers but also to the economy, they said. Consumer lending would promote purchase, stimulate production and growth, and policy-making must be based on that approach. StoxPlus's report on Vietnam's consumer credit in 2016 showed that the credit market has seen amazing leaps in recent years. The outstanding loans of Vietnam consumer finance soared from $\$ 7.3$ billion in 2012 to $\$ 26.55$ billion in 2016 . Though it still accounts for a small proportion ( 9.8 percent by the end of 2016), consumer finance has been growing very quickly. Vietnam has 92 million people with 70 percent of the population aged 15-64, while its GDP growth rate has been stable at over 6 percent in recent years. The total outstanding consumer loans granted to customers in 2015 was VND583 trillion, equivalent to 20.5 percent of the consumption value of individuals and households. If not counting housing loans as per international practice, consumer outstanding loans in 2015 would total VND272.241 trillion (equivalent to 6.62 percent of GDP). The figure is higher than that of China (6 percent) and Japan, but much lower than other developed countries, including the US (17 percent), Europe (14 percent), and Korea over (20 percent). The constant increase of consumption has led to higher demand for consumer loans. Meanwhile, the stable and high economic growth rate helps consolidate people's belief in their income in the future, thus encouraging them to borrow money. Vietnam is in a so-called golden population period with a high percentage of young consumers. As the growth rate of lending to fund production and business has slowed down for several reasons, banks tend to increase consumer credit to offset the slowdown.

\section{Literature review}

\subsection{Demographic characteristics}

Borrowing decisions of customers are different. According to the life-cycle theory of consumption, individuals try to maintain a fairly smooth pattern of consumption over their lifetimes. Campell and Mankiw (1990), Attanasio and Browning (1995), Seater (1997) illustrate that consumers base their lifetime expenditure on the expected flow of income over their lifetimes rather than just their current income. Additionally, the borrowing behaviour of individuals is affected by demographic characteristics.

\section{- Age}

There were several studies worldwide which found that age has a significant effect on customers' choice of instalment credit. SaAadu and Sirmans(1995) illustrated that younger borrowers are interested more in short-term credit and they also expected that people with higher age will negatively impact the probability of choosing this type of product. With the same viewpoint, Park (1993) showed that younger people who have accumulated little wealth and low current incomes tend to have more debt relative to their assets and income as they expect that their incomes will improve and they are typically willing to borrow in order to consume a part of their future income. In detail, Andreou (2011) demonstrated that in Cyprus, from 2003 to 2009, debt-to-income ratio of individuals in the age of under 30 years old. Park (1993) illustrated people between 20 and 34 years of age who make independent financial decisions and rely heavily on future income affect more the consumer borrowing in the long term. On the other hand, there were a minority of research in some selected countries found that age is not a main factor in customers' choice of instalment credit. In British data, Leece (2000) depicted residents with higher age rise the ability of using this product. Paiella and Pozzolo (2007) also agreed with Leece's point of view.

\section{- Sex}

The gender also affects demand for loans. According to Andreou (2011), from 2003 to 2009, in Cyrus, the amount males borrowed was higher than that in females. To be more precise, in 2009, males have loans with the amount of 15 thousand euros while females make loans with the amount of more and less thousand euros. In an analysis, from 2013, men carried $4.3 \%$ more debt than women and the difference in home loans taken out by men and women was $4.9 \%$. Explanation was that males tend to be more comfortable to take debt while females seem to help financial problems quicker and more efficient; that means, generally, men focus on the bigger financial picture and women tend to look at specifics. In an article of press "Journal of Personality and Social Psychology"- U.S, they implemented the survey from 99 university students (53 females), they asked students: "How much money would you be comfortable 
with borrowing each month to spend on things that you might not be able to afford ranging from " $\$ 0$ " to " $\$ 250$ "?", the research result was men being willing to borrow $84 \%$ more money each month (from $\$ 37$ to $\$ 68$ ) while it did not influence women's borrowing.

\section{- $\quad$ Education level}

According the study of Andreou (2011), people in different education levels also have the different interest in instalment loans. In detail, consumers who completed secondary and higher education have the higher amount of instalment loans relative to those with only primary education. In Cyrus, in 2009, in particular, the amount of average loans of people with primary education was somewhere around 9 thousand euros while that of people with secondary education and higher education was approximately 15 thousand euros.

\section{- Income}

In the studies of Andreou (2011) and Park (1993), the distribution of income is a main factor of customers' borrowing behaviour. Individuals in the middle income percentiles (25-75\%) appear to have the highest debt-to-income ratios, followed by those in higher income (75-100\% percentiles) have lower ratios; on the other hand, those in lower income percentiles $(0-25 \%)$ have the lowest ratios (Andreou, 2011). With Park's opinion, middle-income individuals may on average actively borrow future income while high-income individuals generally have less need to borrow and low-income individuals may be afraid to borrow or unable to borrow. In the reports of Hendricks, Gary, Kenwood C. Voumans, and Janet Keller (1973) also show the same point of view. Consequently, the income distribution of consumers in middle income might be associated with more consumer instalment credit.

\subsection{Bank factors}

\section{- Willingness of lender to lend}

Willingness of lender to lend is the readiness of banks to provide loans to consumer.

According to Christa Hainz and Nikolay Hristov (2017) three levels to assess bank readiness for customers included accommodating, normal and restrictive. Park (1993) started that when financial institutions tighten lending standards, many customers will tend to restrict consumption or find other means of financing. Therefore, this fact leads the slow growth of CIC. On the other hand, this study also shows that, at different economic periods, the degree of tightening or loosening of banks' policies towards lending is also different.

\section{- Bank's interest rate}

Interest rates at banks are always of prime interest when customers decide to make a loan. Monetary contraction and interest rate increase reduce spending directly; both also reduce spending indirectly by shrinking bank loan supply (Bernanke and Blinder, 1988).

According to Ciaran (2017), As interest rates rise, loans become more expensive but interest rates on deposits also increase. Conversely, when interest rates fall, customers tend to borrow more than they save. And of course, consumer loans are also increase when interest rate's bank went to go down. This suggested that bank interest rates play an important role and have a direct impact on the growth of consumer credit products in particular and other credit products in general.

\subsection{Customer Factors}

\section{- Income distribution}

For households and individuals, income is the sum of all the wages, salaries, profits, interest payments, rents, and other forms of earnings received... in a given period of time.

Income is a factor that has a significant impact on consumer demand for consumer loans. In accordance with Park (1993), the majority of low-income and middle-income clients tended to borrow more than those with higher incomes. Accordingly, as the average income increases in the economic period, the share of consumer loans also decreases considerably. In addition, Gene Amromin, Leslie McGranahan, Diane Whitmore Schanzenbach (2015), where low-income people live may play a large role in their ability to access credit. Hence, the relationship between income distribution and consumer borrowing capacity is inversely ratio.

\section{- Relative interest rate}

The relative interest rate is not a real number, it is a prediction or guess used by buyers and sellers in the international market place. But in this case, "Relative interest rate" is the relative interest rates on assets and liabilities.

In accordance with Park (1993), Clients often have more financial options, so they will choose the least expensive method. Customers will have a balance between assets and debt, if the interest rates on debt and income from financial assets are large, customers will tend to use assets instead of interest. In addition, many people have deposits at banks but still borrow money to buy cars, because they see the difference in interest rates are not much, so they accept interest payments to retain the savings deposit. at the bank. It all depends on the difference between interest rates on financial markets. Therefore, the interest rate also has a great influence on the growth of instalment credit.

\section{Methodology}

The study used an in-depth interview with experts in the field of banking - finance and survey-questionnaires. In-depth interviews were conducted in September of 2018 to explore initial factors that affect consumer instalment and complete questionnaire. Surveyquestionnaires were asked in three months from October to December of 2018, with range of people, including men and women from ages of 20 to 65 , with different professions, incomes and consumer demand, they included: i) bank staff or trainees at the bank; ii) people in start-up forums; iii) consumers in shopping centres and shops selling instalment products. The research collected 580 questionnaires, of which 600 were used for data analysis process, 20 questionnaires were rejected because of the lacking information which is needed for the research. Statistic method was used for data procession.

\section{- Description}

In the survey, respondents were divided into the following main groups: i) age from under 25 to over 55, ii) income from less than 10 million $\mathrm{V}^{\text {nd }}$ to over 50 million $\mathrm{V}^{\text {nd, }}$ iii) work from state, private, and other; iv) education from elementary to postgraduate.

Table 2: Result in survey - questionnaires

\begin{tabular}{|l|l|l|}
\hline Group of Stakeholder & Respondents & Percent \\
\hline Sex & 244 & $42,06 \%$ \\
\hline Male & 336 & $57,94 \%$ \\
\hline Female &
\end{tabular}




\begin{tabular}{|l|l|l|}
\hline Other & \multicolumn{2}{|l|}{} \\
\hline Age & 85 & $14,65 \%$ \\
\hline Under 25 & 227 & $39,13 \%$ \\
\hline $25-35$ & 163 & $28,10 \%$ \\
\hline $35-45$ & 91 & $15,68 \%$ \\
\hline $45-55$ & 16 & $2,44 \%$ \\
\hline Over 55 & \multicolumn{2}{|l|}{} \\
\hline Income & 152 & $26,21 \%$ \\
\hline Under 10 million Vnd & 259 & $44,66 \%$ \\
\hline $10-20$ million Vnd & 127 & $21,89 \%$ \\
\hline $20-50$ million Vnd & 42 & $7,24 \%$ \\
\hline Over 50 million Vnd & 425 & $73,28 \%$ \\
\hline Use/Do not used consumer instalment credit \\
\hline Use & 425 & $26,72 \%$ \\
\hline Usedn't & 155 & \\
\hline
\end{tabular}

Source: Primary data

From the above table, there are many criteria to classify the results of survey. In 580 people participated in the survey, including 244 men and 334 women, this shows that men are more interested in CIC products than women. It is understandable because men often have higher demand for loans than women in buying houses, cars or telephones etc. As many as 227 people in the survey were aged 25 to 35 . Of the 227 respondents aged 25 to 35 , more than $62 \%$ had or were using the CIC product. This result is perfectly consistent in Vietnam, by people aged 25-35 who are mostly middle-income range of 10 to 20 million Vnd per month, not enough to save but still have the ability to pay for a house or car instalment purchase. This is consistent with the results we obtained from the survey of 580 people on the income criterion: $44,66 \%$ of those interested in CIC products are people with income of 10-20 million Vnd per month.

\section{Discussion}

\subsection{Demographic factors}

According to interviewee a specified CIC will be targeted to the different kinds of customers to provide the product. For example, instalment loans for laptop, mobile phones and other small items will focus on university students and people with low income while instalment loans for buying house, apartment, car or other things with relatively large amount of money will be targeted young families with stable income. Thus, in Vietnam, as assessing the growth of CIC, the demographic factors have a great impact, which affect the decision for using the product of the customers and the product design of bank to suit with targeted customers.

\section{- Income}

Interviewee said that in all consumer instalment loans, almost of banks are concerned about stable income streams for their customers. Banks expect customers will have a source of income to pay their loans in each payment period rather than basing on their collaterals or other sources. For every personal finance consultant, the first concern about his or her customer is the payment ability. A loan is accepted by the bank when the client satisfies sufficiently large and sound financial capacity to fulfil their repayment obligations. Banks should carefully consider the doubtful sources of repayment or the unstable sources. As a result, income may be the most important factor in demographic factors. Vietnam has a per capita income of about $\$ 2,186$ by 2016 , according to the World Bank, a very large consumer market. In addition, the size of this market has increased steadily and steadily with an annual average growth rate of over $6 \%$ in the last 30 years. Relatively high- and stable-income growth has high expectations of future income and stable macroeconomics are two important factors for residences willing to increase their debt to consumption.

Table 3: The survey results about income (people are using products or people used this products)

\begin{tabular}{|l|l|l|}
\hline Income & Quantity & Proportion \\
\hline Under 10 million Vnd & 46 & $10,82 \%$ \\
\hline $10-25$ million Vnd & 232 & $54,59 \%$ \\
\hline 25-50 million Vnd & 113 & $26,59 \%$ \\
\hline Over 50 million Vnd & 34 & $8,00 \%$ \\
\hline Total & 425 & $100,00 \%$ \\
\hline
\end{tabular}

Source: Primary data

According to our survey, 460/580 people surveyed agreed that income has the greatest influence of the growth of consumer instalment credit. Accordingly, the customers who use this product are mainly individuals and households with income from 10 to 25 million Vnd, accounting for $55 \%$ in total. The demand for this product of the group of people earning from 25 to 50 million Vnd per month is also relatively high, reaching about $26.6 \%$ or $113 / 425$ people taking part in our survey. Additionally, products used by this group are loans for buying house, apartment and car. The number of people with income under 10 million Vnd per month who use this product is $10.8 \%$. The survey result shows that this group mostly borrows to buy relatively small economic items such as mobile phones and laptops. Finally, the group of people earning over 50 million Vnd per month is hardly interested more in these products for they have a strong economic power, this rate is only $8 \%$ respectively $34 / 425$ people. It is undeniable that in Vietnam, people with average income are most interested in CIC and the majority of low-income customers want to use this product but they face some limitations while high income people focus less on this product.

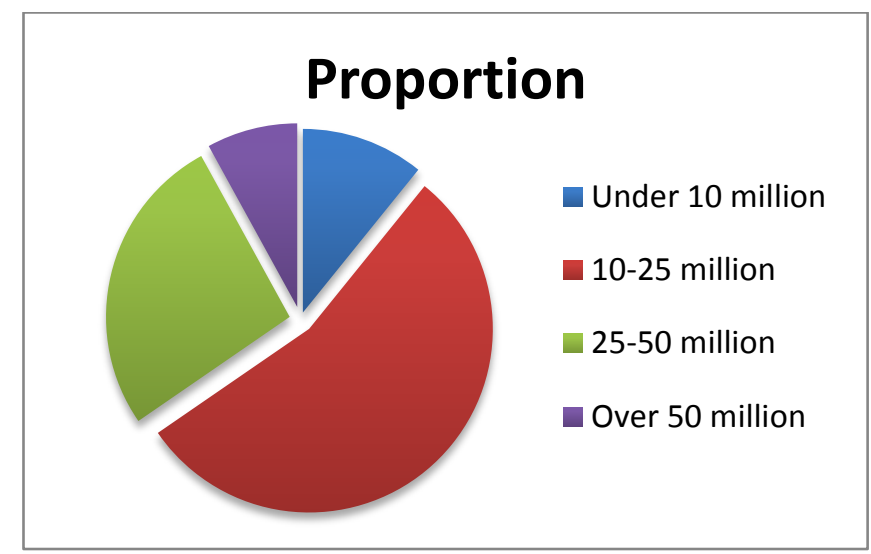

Source: Primary data

Fig. 4: The survey results about income (people used/are using products)

\section{- Age}

The factor with the second level of influence is the age group. In Vietnam, recently, the rate of young people in working age accounts for $51.6 \%$ of 90 million population, this is largely potential for the growth of the consumer credit in general and the consumer instalment credit in particular. Particularly, nearly 16 million Vietnamese people now meet the basic requirements about the age to become customers of the consumer credit (Stoxlus, 
2017). According to the research data from the unsecured loan agreement contracts, people aged 27-35 years have the highest borrowing demand. A good reason for this fact might be this age group is either starting a new business or building or buying the house to stabilize their life. People in this age group see it as a development opportunity so they actively seize this. In this age group, almost people appear the legitimate needs for consumer instalment loans and the borrowers have enough "knowledge" to analyse the benefits and harms of bank instalment loans for consumption

Table 4: The survey results about the age group

\begin{tabular}{|c|c|c|c|c|c|c|c|c|c|c|}
\hline $\begin{array}{c}\text { Age } \\
\text { group }\end{array}$ & Using & Percentage & $\begin{array}{l}\text { Don't } \\
\text { Use }\end{array}$ & Percentage & Used & Percentage & $\begin{array}{l}\text { Will } \\
\text { use }\end{array}$ & Percentage & $\begin{array}{l}\text { Don't have } \\
\text { demand }\end{array}$ & Percentage \\
\hline Under 25 & 89 & $23.42 \%$ & 55 & $27.50 \%$ & 1 & $2.22 \%$ & 63 & $50.40 \%$ & 1 & $3.33 \%$ \\
\hline $25-35$ & 193 & $50.79 \%$ & 23 & $11.50 \%$ & 4 & $8.89 \%$ & 48 & $38.40 \%$ & 4 & $13.33 \%$ \\
\hline $36-45$ & 64 & $16.84 \%$ & 34 & $17.00 \%$ & 21 & $46.67 \%$ & 11 & $8.80 \%$ & 4 & $13.33 \%$ \\
\hline $46-55$ & 20 & $5.26 \%$ & 62 & $31.00 \%$ & 14 & $31.11 \%$ & 3 & $2.40 \%$ & 9 & $30.00 \%$ \\
\hline Over 55 & 14 & $3.68 \%$ & 26 & $13.00 \%$ & 5 & $11.11 \%$ & 0 & $0.00 \%$ & 12 & $40.00 \%$ \\
\hline Total & 380 & $100.00 \%$ & 200 & $100.00 \%$ & 45 & $100.00 \%$ & 125 & $100.00 \%$ & 30 & $100.00 \%$ \\
\hline
\end{tabular}

Source: Primary data

In the survey, 60 people agreed that age is an important factor determining the growth rate of CIC. Specifically, 380 people are using this product and 45 people had used this product. The age most concerned about CIC is from 25 to 35 years of age, accounting for $50.8 \%$. They are young, newly married and start to settle their income. Followed by the group under 25, only $89 / 380$ people are using the product in this age group. Older customers with over 36 years of age tend to be less interested in borrowing in the instalment way for they usually emphasize the certainty, they want to save enough money to buy rather than they buy then pay later. As a result, people in 25-35-year olds are using this product the most, people over 35 years of age had used or do not have demand to use while people under 25 are potential customers in the future.

In the quantity of people who are not using the product, there are 125 individuals believing that they will use in the future. this is a positive signal for instalment consumer credit. people pay more their attention to this kind of product. In additions, 63 individuals under 25 have the borrowing demand for their expenditure but at this quite young, they hardly meet the critical lending requirements of commercial banks about financial ability or stable career. that is the reason why they are potential customers in the coming years. while people at 46 and more nearly do not interested in consumer credit, only $3 / 125$ individuals at this age think that they will pay attention to product in the next years. explaining this fact, they have owned a quite large of wealth which are accumulated within their life or they are reserved in borrowing from banks

\section{- Educational level}

Educational level is also a significant factor. In all loan agreement contract of every commercial banks, they mention borrower's educational level as a valuable element in the decision-making process. According to the latest report, there are $80 \%$ of borrowers with high school diploma or more.

Table 5: The educational level (customers are using product or people had used product)

\begin{tabular}{|l|l|l|}
\hline Educational level & Quantity & Ratio \\
\hline Primary school & 40 & $9.41 \%$ \\
\hline Secondary school and high school & 75 & $17.65 \%$ \\
\hline University & 189 & $44.47 \%$ \\
\hline Higher education & 121 & $28.47 \%$ \\
\hline Total & 425 & $100.00 \%$ \\
\hline
\end{tabular}

Source: Primary data

In the 425 people using the product in survey, the result shows that the majority of people with college and postgraduate qualifications use this product, up to $300 / 425$ people in this category.

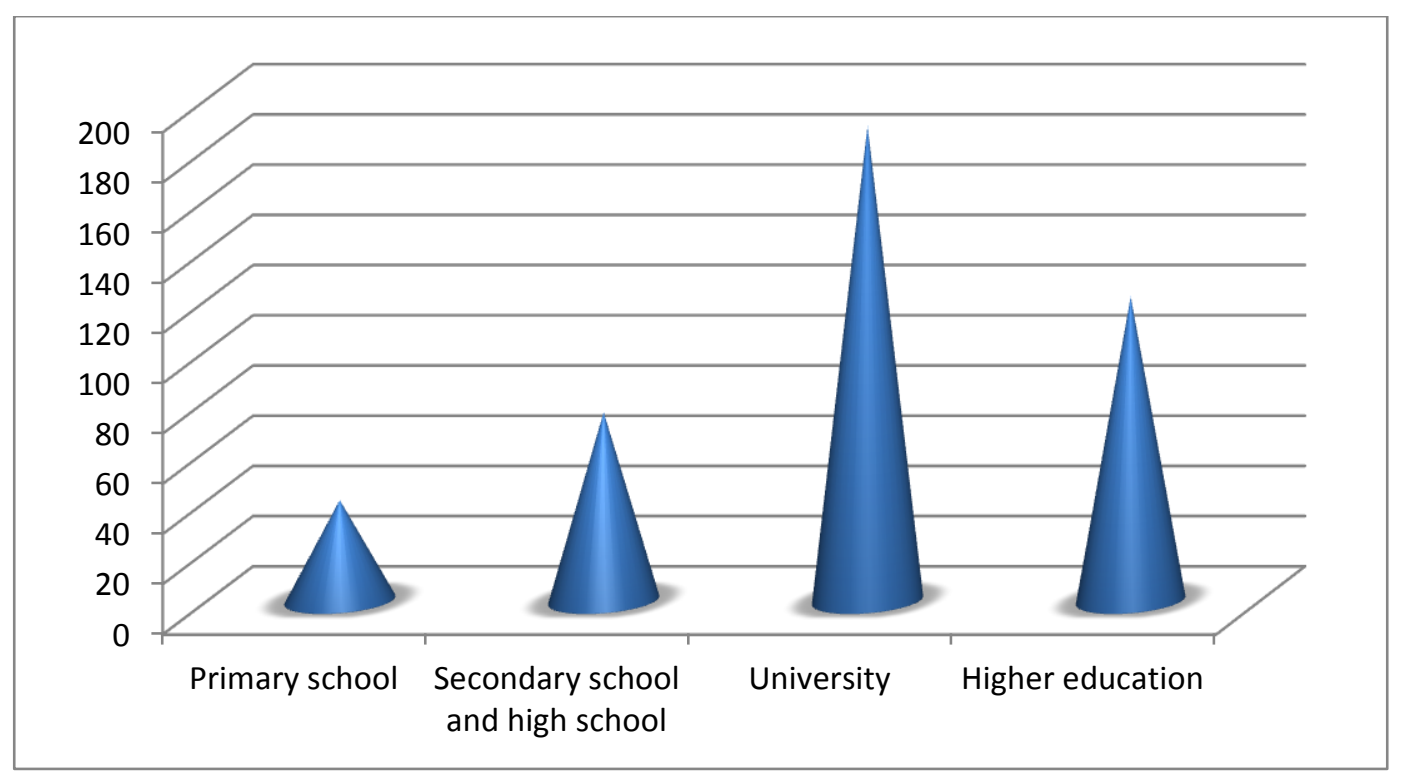

Fig. 5: Educational level (customers used/are using product) 
The reasons may be due to their higher awareness of the product and better understanding as well as the psychology of borrowing and how to balance the cost of debt repayment in line with income. The remaining groups with primary and secondary education also use product also those are minority groups, with about $27 \%$ of people in this group interested in CIC. With limited knowledge of consumer credit, they are often afraid to borrow the amount of money for consumption due to they do not want to deduct a portion of their income to pay off their loans and they fear what will happen when they are unable to repay. In recent years, the educational size at all levels, especially the university level, has a relatively high growth, proving that Vietnamese people's intellectual level has been step by step expanded and improved markedly. In the large cities and provinces of Vietnam, most of the population have reached the high school education level. When people understand more about credit, they will reduce their prejudices for borrowing. This fact is a positive signal for the potential of consumer instalment credit. We conclude that in Viet Nam, almost of people with university level and post-graduate educated focus most on the product and other groups with lower educational level have the relatively small rate of the using level.

\section{- $\quad$ Sex}

Sex also affects the growth rate of the product but its impacting level is not high. In general, there is a relative difference between men and women when they decide to use this product. In the 580 respondents, women account for more than half (about 57.94\%) and the ratio of men is $42.06 \%$. The survey found that women are more likely to have access to credit channels and also have higher demand for the consumer credit than men

Table 6: The survey results about sex

\begin{tabular}{|l|l|l|}
\hline Sex & Quantity & Rate \\
\hline Male & 244 & $42.06 \%$ \\
\hline Female & 336 & $57.94 \%$ \\
\hline Total & 580 & $100.00 \%$ \\
\hline
\end{tabular}

Source: Primary data

According to some financial experts, this showed that habits of Vietnamese people in general, women in particular, increasingly change, Instead of saving mainly, currently, they are moving to borrow for their consumption and procurement of essential needs. The conception "Men build houses, women build homes" is still valuable but in today's context, women are not only responsible for keeping the fire in their family but also the financial manager and the participant in important decisions of their family. Compared to men, nowadays, women have more spending needs - not only serving their own needs, such as fashion, beauty, health care and social relations, but also on the needs of their family - the things that were previously usually the "responsibility" of the man. Thus, the financial autonomy of women in the family has improved compared to before. Additionally, the fact that many women with consumer install loans means that they are able to repay their debts. Surveys show that the number of women having their jobs and medium income is on the rise.

\section{2 Customer factors}

\section{- $\quad$ Relative Interest Rates}

In the group of macroeconomic factors, interest rate impacts most in consumer instalment loans. The expectation that the increase in the interest rate would make the bank's consumer instalment loans decreased. According to the estimated results, In the 425 people voted (use), there are 415 people survey agree that interest rate has the greatest influence of the growth of consumer install credit while people who don't care about interest rate only have 10 people uith level from 0 - Not interested to 5 - Very interested.

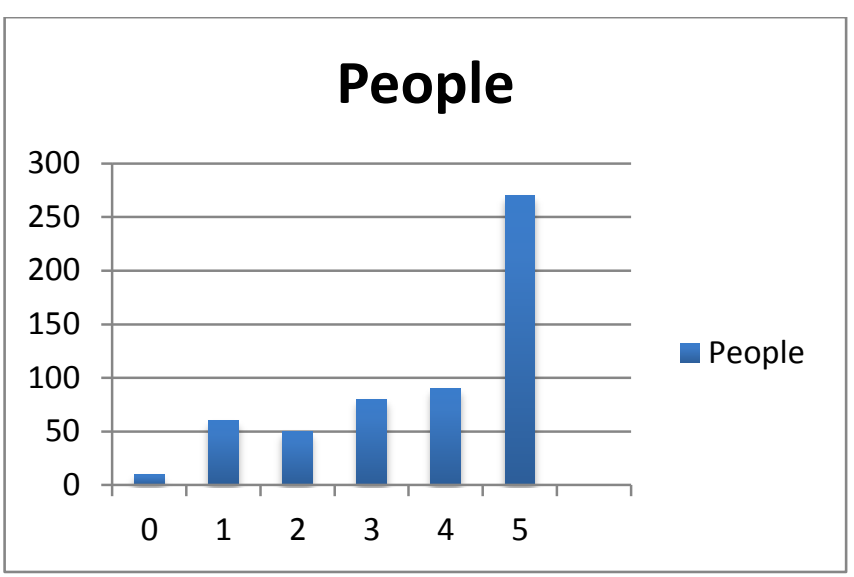

Source: Primary data

Fig. 7: The survey results about the relative interest rate

Unlike most of market-adjusted interest rate loans, interest rate of personal loan is generally high. Besides, interest rate is not flexible, individual customers don not be sensitive to interest rate, they usually concern about amount of money that have to pay monthly.

\section{- Income distribution of customer}

According to results, the number of people who have income do not meet with the demand for bank loans is $13.5 \%$. Results from survey also indicated that up to $80 \%$ of people who are under 25 years old with low-income and unstable job often have little chance to use consumer loans.

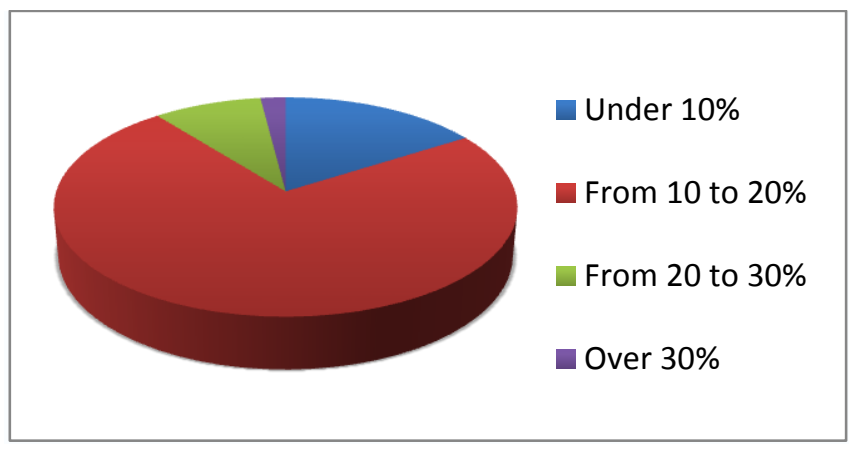

Source: Primary data

Fig. 8: Percentage from income extracted for instalments

Figure 8 showed that, respondents spend less than $10 \%$ of their income to pay instalments take $16 \%$ in total. Additionally, group spent $10-20 \%$ of their income for instalment payment reached the biggest part $73.3 \%$ of total. The group which use $30 \%$ of their income for payment is the smallest. Therefore, because of individual' financial difficulty, almost Vietnamese consumer spent small part of their income for payback the loans.

\subsection{Banks factors}

\section{- Willingness of lenders to lend of banks}

This factor considered dealt mainly with the demand for CIC. Supply conditions may also affect the quality of CIC. Tightening of lending standards by financial institutions may force many customers with heavy credit needs to defer consumption and many others to find other financing means. Hence, the reluctance of 
lenders to extend credit may result in slow growth of consumption and even slower growth of consumer credit.

Table 7: The survey results about the willingness of lenders to lend

\begin{tabular}{|l|c|c|c|c|c|}
\hline Levels & 0 & 1 & 2 & 3 & 4 \\
\hline Amount of people & 20 & 40 & 70 & 100 & 170 \\
\hline
\end{tabular}

Source: Primary data

Another factor affecting the capital adequacy is the interest rate is the willingness of lenders to lend. According to our survey, over 90 percentage of people surveyed agree that willingness of lenders to lend has influence of the growth rate of product. Accordingly, there are around 30 percentage of people saying that this factor is an important factor determining the growth rate of consumer instalment loans. The willingness of lenders to lend has a significant impact on the customer's decision to use the product. If the bank has the policy, cumbersome, time-consuming to make customers have psychological anxiety and do not want to use. Any customer would like to use the products that they are easily accessible without spending too much time waiting.

\section{Recommendation}

From the results of questionnaire, in-depth interview and research on CIC in emerging country with Vietnam for case study, they showed that the number of people being interested in CIC is more and more increasing and having demand on using CIC higher than the past. Nowadays, CIC ratio is just approximate 5-10\% of total outstanding loans, whereas in developed countries it is usually $40-$ $50 \%$. This will be the one of forces for national consumption and that of the main factor to develop economic. Therefore, some recommendations were proposed to promote the development of CIC include:

\section{- For the Government and the Central bank}

For the consumer lending market in Vietnam to catch up with the development of the world market, it is necessary to complete legal issues for consumer finance to build the foundation for commercial banking system and financial companies operate. In addition, they also need to create a fair competitive market. Firstly, on the policy of developing CIC, the government and central bank should: i) Improving the legal policies for CIC products, minimize prolix procedures and give effective and safe forms of asset supervision; ii) Developing payment channels, electronic credit to help customers to keep track of repayment plans and automatic repayment on time. Besides, authorities should continue encourage and improve the change of everyone to approach finance, especially, those who have low incomes, without a history of credi), and help smooth consumption patterns between cycles of income fluctuations. Thus, it is required to have a part in improving the quality of life and increase equitable society. Furthermore, to create the support channels to ensure that borrowers could approach the inspection and supervision agencies when they have complained about loans is necessary. To carry out close supervision of high-risk credit institutions, ensuring that consumer lending companies have a consistent and sustainable business model that prohibits behaviour fraudulent, anti-money laundering and illegal business.

\section{- For banks}

Through the questionnaires illustrated consumers want to use CIC usually care about the interest rate and the quality of the bank.
Besides, we also have some norm that everyone wants to know, such as: banking system, the time of loan or regulations of commercial banks. Moreover, they have desire to have a predetermined value of the products and services they are interested in, and have a monthly repayment plan to get a full set value of the product. To find the right customer needs and have the ability to pay debts, the bank should design CIC for each specific product and find out people who have demand on each product and have good cash flow for repayment. Additionally, concerning about interest rate, generally it higher than other product of bank because of evaluation and monitoring of cash flow in long-term is riskier and the bank hasn't been able to accurately control the cash flow of customers and awareness of customers in repayment. Therefore, they could make interest rate lower and flexible. In addition, it is necessary to raise awareness of people about consumer financial services with good counselling campaigns both before and during the customer service process. It can make the number of people using CIC grow up.

Besides, banks should enhance the dynamics, accountability and transparency of regulations on consumer lending. Other regulations to protect borrowers may also be introduced such as the right to remove a loan - allowing the borrower to terminate the credit agreement without having to fulfil the penalty obligations, usually in a period of 14 days after the contract is terminated; responsible lending requirement - requires a responsible credit institution not to lend to borrowers without the ability to repay.

\section{Conclusion}

It can be seen that in a country with a low per capita income like Vietnam with per capita income around USD 2500, it is difficult to buy a house or a car based on these incomes. Consumption credit is also a necessary product and potential development in developing country that is crucial force for enhancing national consumption, therefore, being the main factor to boost the economy.

In spite of efforts in data collection, the compilation of data, in some aspects, is not comprehensive. The study could be further accomplished by incorporating more variables and expanding sample size. Nevertheless, findings have been indicated on scientific foundations.

\section{References}

[1] Attanasio, O.P., Browning, M., 1995. Consumption over the life cycle and over the business cycle. American Economic Review 85, p1118-1137.

[2] Ben S. Bernanke; Alan S. Blinder (1988), Credit, Money, and Aggregate Demand, The American Economic Review, Vol. 78, No. 2, Papers and Proceedings of the One-Hundredth Annual Meeting of the American Economic Association. (May, 1988), pp. 435-439, retrieved at: http://www.economia.pucrio.br/mgarcia/Macro\%20II\%20$\%$ 20Mestrado/BernankeBlinder.pdf

[3] Board of Governors of the Federal Reserve System (2006), Senior Loan Officer Opinion Survey on Bank Lending Practices, retrieved at https://www.federalreserve.gov/boarddocs/rptcongress/b ankruptcy/bankruptcybillstudy200606.pdf. 
[4] Campbell, J., Mankiw, N.G., 1990. Permanent income, current income, and consumption. Journal of Business and Economic Statistics, Vol. 8, 265-279.

[5] Christa Hainz and Nikolay Hristov (2017), Credit Crunch Indicator: Perceptions of the Willingness of Banks to Lend and Firms Experience in the Credit Market, CESifo Forum 2/2017, June Volume 18, retrieved at https://www.cesifo-group.de/DocDL/CESifo-Forum2017-3-hainz-hristov-credit-crunch-june.pdf.

[6] Ciaran John (2017), The Effect of Interest Rates on Consumer Behaviour, retrieved at: https://pocketsense.com/effect-interest-rates-consumerbehavior-8017654.html.

[7] Felicia Omowunmi Olokoyo (2011), Determinants of Commercial Banks' Lending Behavior in Nigeria, International Journal of Financial Research Vol. 2, No. 2; July 2011, p61-73.

[8] Gene Amromin, Leslie McGranahan \& Diane Whitmore Schanzenbach, (2015), "Consumer credit trends by income and geography in 2001-12", The Federal Reserve Bank of Chicago, Number 342/2015, retrieved at:

https://www.chicagofed.org/ /media/publications/chicag o-fed-letter/2015/cfl342-pdf.pdf.

[9] Hendricks, Gary, Kenwood C. Voumans, and Janet Keller (1973). Consumer Durables and Installment Credit: A Study of American Households. Survey Research Center, University of Michigan.

[10] Maria Gullgren and Inga-Lill Soderberg (2013), The relationship between consumer characteristics and mortgage preferences: A case study from Sweden, International Journal of Housing Markets and Analysis, Vol. 6, no 2, p. 209-230.

[11] Mathias Klein and Christopher Krause (2014), "Income Redistribution, Consumer Credit, and Keeping up with the Riches", RUHR economic papers, No 509, retrieved at: http://www.rwiessen.de/media/content/pages/publikationen/ruhreconomic-papers/REP_14_509.pdf.

[12] Leece, D. (2000), Household choice of fixed versus floating rate debt: a binominal probit model with correction for classification error, Oxford Bulletin of Economics and Statistics, Vol. 62 No. 1, pp. 61-81
[13] Paiella, M. and Pozzolo, A. (2007), Choosing between fixed and adjustable rate mortgages, Discussion Paper No. 33/07, Facolta di Economia, Universita degli Studi del Molise, Campobasso.

[14] Robert B.Avery, Gregory E.Elliehausen, Arthur B.Kennickell (1987), Changes in Consumer Installment Debt: Evidence from the 1983 and 1986: Surveys of Consumer Finances, Board of Governors of the Federal Reserve System (U.S.), issue Oct, pages 761-778.

[15] Robert Scott and Steven Pressman (2013), Household Debt and Income Distribution, LIS Working Paper Series, No. 589, Luxembourg Income Study, retrieved at: https://www.econstor.eu/bitstream/10419/95518/1/74960 8382.pdf

[16] Sangkyun Park (1993), The determinants of consumer instalment credit, retrieved at: https://pdfs.semanticscholar.org/7b6a/271e5b94b38e7cbc d8a6b7d86431b97d94d3.pdf.

[17] Sa-Aadu, Jarjisu, and C. F. Sirmans. 1995. Differentiated Contracts, Heterogenous Borrowers, and the Mortgage Choice Decision. Journal of Money, Credit, and Banking 27:498-510

[18] Seater, J.J., 1997. An optimal control solution to the liquidity constraint problem. Economics Letters 54, $127-134$.

[19] Sofia N.Andreou (2011), The borrowing behaviour of households: Evidence from the Cyprus Family Expenditure Surveys, Cyprus Economic Policy Review, Vol. 5, No. 2, pp. 57-83.

[20] Stoxplus (2017), Vietnam Consumer Finance Report, retrieved https://research.vietnambusiness.tv/consumerfinancerepo rt2017-demo-170510065248.pdf

[21] Thomas A. Durkin, Gregory Elliehausen, Michael E. Staten (2014), Consumer Credit and the American Economic, Oxford University Press.

[22] United Nations (2015), Consumer credit and Banking, Project on Strengthening Technical Competency for Consumer Protection in ASEAN, retrieved at: https://asean.org/storage/2012/05/Consumer-CreditBanking-Module-Final-21Dec15.pdf 